\title{
Metacognitive Reading Strategies among Undergraduates
}

\author{
Azizah Rajab, Hamidah Abdul Rahman, Shah Rollah Abdul Wahab, Faizah Mohd Nor, Wan Zarina \\ Wan Zakaria, and Wan Zahidah Rajim
}

\begin{abstract}
The purpose of this study is to investigate the metacognitive reading strategies employed by fifty four undergraduates in Universiti Teknologi Malaysia (UTM). A questionnaire adapted from Metacognitive Awareness of Reading Strategies Inventory (MARSI) was used and data were analyzed using the Statistical Package for Social Science (SPSS) version 20 for descriptive statistics. Findings indicated that the undergraduate students have a great preference in utilizing the Problem-Solving Strategies as compared to Global Reading Strategies or Support Reading Strategies. The results of this study should help language practitioner to train students on how to adapt or use different strategies effectively when reading different types of text.
\end{abstract}

Index Terms-Global reading, metacognitive reading strategies, problem-solving, support reading.

\section{INTRODUCTION}

Reading is an essential skill for everyone. Through reading, we not only gain knowledge but also learn new information. Reading provides opportunities for readers to learn many mechanisms of language such as vocabulary, grammar, punctuation and sentence construction as well as how to write paragraphs and texts. Readers can improve their reading skills when they are aware of their reading strategies. Pressley and Afflerbach [1] defined efficient readers as strategic readers who are conscious of their reading materials and able to demonstrate good reading strategies in order to comprehend the text. On the other hand, Grabe [2] argued that reading should have a purpose, should be interactive, comprehensive and flexible while developing gradually because reading not only involves motivation, but also provide an interaction with the readers' background knowledge and the information in the printed text. In order to read effectively, readers must have some sort of expectation in order to understand what he/she is reading. Readers must believe that fluency does not happen all of a sudden, because fluent reading is achieved from continuous effort and gradual improvement through the employment of various strategies. Good readers must also have the ability to comprehend, evaluate and synthesize a text while reading other sources. Baker and Brown [3], Shmais [4] and Cubukcu [5] agreed that good readers in L1 (first

Manuscript received February 2, 2016; revised June 29, 2016.

Azizah Rajab is with the Language Academy, Universiti Teknologi Malaysia, Malaysia (e-mail: r_azie@yahoo.com/azizah@utm.my).

Hamidah Abdul Rahman and Shah Rollah Abdul Wahab are with the Faculty of Management, Universiti Teknologi Malaysia, Malaysia (e-mail: midahp@yahoo.com).

Faizah Mohd Nor and Wan Zarina Wan Zakaria are with the Language Academy, Universiti Teknologi Malaysia, Johor Bahru Campus, Malaysia.

Wan Zahidah Rajim is with Faculty of Education, Universiti Teknologi Malaysia, Johor Bahru Campus, Malaysia. language) and L2 (second language) are good thinkers who can function spontaneously in recognizing problems and adopt diverse reading strategies to predict new information while reading. However, many readers tend to apply less effective strategies and do not monitor activities while reading academic texts.

Anderson [6] stated that metacognition combines a variety of thinking and reflective processes. The metacognition strategies can be classified into five primary components: 1 ) preparing and planning for learning, 2) selecting and using learning strategies, 3) monitoring strategy use, 4) orchestrating various strategies, and 5) evaluating strategy use and learning. According to O'Malley and Chamot [7], metacognitive strategies involves both knowledge about learning known as metacognitive knowledge and control or regulation of learning which is recognized as metacognitive strategies. Metacognitive knowledge refers to knowledge of one's own cognitive processes and those of others whereas learning regulation involves the use of metacognitive strategies. Slavin [8] stated that metacognitive learning strategies are used by students to assess their own understanding, figure out how much time they will need to learn, choose and evaluate effective plans. Likewise, Brown [9] asserted that metacognitive reading strategies consist of checking the possible outcomes of any attempt to solve a problem, monitoring the effectiveness of any attempted action, and testing, revising, plus reviewing strategies for learning. A study by Sheorey and Mokhtari [10] showed that successful readers have a higher metacognitive awareness as compared to less successful readers. Thus, metacognitive reading strategies help students to monitor or regulate their thoughts and can be used either deliberately or automatically [11]. Wenden [12] asserted that students' metacognitive awareness played a part in the effective learning, while Magno [13] believed that the use of metacognitive reading strategies leads to a profound learning experience and improved performance. Hence, L2 readers are encouraged to use metacognitive reading strategies to improve their reading skills in order to enable the effective and efficient employment of reading strategies.

Consequently, this study focuses on the metacognitive reading strategies used by Mokhtari and Reichard [14] when reading academic texts. These strategies are subdivided into three categories; Global Reading Strategies, Problem-solving Reading Strategies and Support Reading Strategies. Many researchers of metacognitive reading strategies such as Snow, Burns, and Griffin [15], Pressley and Afflerbach [1], Paris and Winograd [16], Baker and Brown [3] and Flavell, [17], presumed that skilled reading is interrelated with the readers' metacognition. Readers who have high awareness of metacognitive reading strategies are recognized as skilled 
readers. Therefore, this study was conducted to determine the reading strategies employed by Universiti Teknologi Malaysia undergraduates' while reading academic texts to determine whether they are categorized as a successful readers or unsuccessful readers.

\section{Methodology}

\section{A. Instrument, Sample, Analysis}

In this study a set of questionnaire was used to assess metacognitive awareness and the perceived use of reading strategies while reading academic texts which was adapted from the Metacognitive Awareness of Reading Strategies Inventory [MARSI-4]. The respondents of this study were 54 undergraduates pursuing Bachelor of Engineering (Mechanical) degree in Universiti Teknologi Malaysia, Skudai. The questionnaire consisted of 30 items with 3 strategy subscales, global reading strategies (13 items), problem-solving reading strategies ( 8 items) and support reading strategies (9 items) as seen in Table I. A 5-point Likert scale was used with a scale of 1 - I never or almost never do this, 2 - I do this only occasionally, 3 - I sometimes do this, 4 - I usually do this and 5 - I always or almost always do this. The data were analyzed using the Statistical Package for Social Science (SPSS) 20 to find the mean and create categories of three frequency levels, low, moderate and high. High frequency indicated a high level of reading strategies and low frequency showed a low level of reading strategies.

TABLE I: DistRIBUTIONS OF METACOGNITIVE READING STRATEGIES ITEMS
\begin{tabular}{|c|c|c|}
\hline $\begin{array}{c}\text { Metacognitive } \\
\text { Reading Strategies }\end{array}$ & Item & Total \\
\hline Global (GLOB) & $\begin{array}{c}\text { S1,S3,S4,S7,S10,S14, } \\
\text { S17,S19, S22, } \\
\text { S23,S25,S26,S29 }\end{array}$ & 13 \\
\hline $\begin{array}{c}\text { Problem-solving } \\
\text { (PROB) }\end{array}$ & $\begin{array}{c}\text { S8,S11,S13,S16,S18,S } \\
21, \text { S27,S30 }\end{array}$ & 8 \\
\hline Support (SUP) & $\begin{array}{c}\text { S2,S5,S6,S9,S12,S15, } \\
\text { S20,S24, S28 }\end{array}$ & 9 \\
\hline
\end{tabular}

TABLE II: LEVEL OF READING STRATEGIES

\begin{tabular}{|l|l|}
\hline Categories/ Level & Mean Score \\
\hline Low & $1.00-2.49$ \\
\hline Moderate & $2.50-3.49$ \\
\hline High & $3.50-5.00$ \\
\hline
\end{tabular}

\section{RESULTS}

TABLE III: FREQUENCY AND LEVEL OF GLOBAL READING STRATEGIES Global Reading Strategy

\begin{tabular}{|c|c|c|c|}
\hline Categories & Levels & Frequency & $\begin{array}{l}\text { Percent } \\
(\%)\end{array}$ \\
\hline Low & $2.49-3.50$ & 2 & 3.7 \\
\hline Moderate & $2.50-3.49$ & 27 & 50.0 \\
\hline High & $3.50-5.00$ & 25 & 46.3 \\
\hline \multicolumn{2}{|l|}{ Total } & 54 & 100.0 \\
\hline
\end{tabular}

TABLE IV: FREQUENCY AND LEVEL OF PROBLEM-SOLVING READING STRATEGIES

\begin{tabular}{|l|l|l|l|}
\hline \multicolumn{4}{|l|}{ Problem-solving Reading Strategy } \\
\hline Categories & Level & Frequency & Percent (\%) \\
\hline Low & 2.49 or lower & 1 & 1.9 \\
\hline Moderate & $2.50-3.49$ & 13 & 24.1 \\
\hline High & 3.50 or above & 40 & 74.1 \\
\hline Total & 54 & 100.0 \\
\hline
\end{tabular}

TABLE V: FREQUENCY AND LEVEL OF SUPPORT READING STRATEGIES Support Reading Strategies

\begin{tabular}{|l|l|l|l|}
\hline Categories & Levels & Frequency & Percent (\%) \\
\hline Low & 2.49 or lower & 4 & 7.4 \\
\hline Moderate & $2.50-3.49$ & 28 & 51.9 \\
\hline High & 3.50 or above & 22 & 40.7 \\
\hline Total & 54 & 100.0 \\
\hline
\end{tabular}

\begin{tabular}{|c|c|c|c|c|c|}
\hline Strategies & $\begin{array}{c}\text { No of } \\
\text { students }\end{array}$ & Minimum & Maximum & Mean & $\begin{array}{c}\text { Standard } \\
\text { Deviation }\end{array}$ \\
\hline $\begin{array}{c}\text { Global } \\
\text { Reading } \\
\text { Strategies }\end{array}$ & 54 & 1.69 & 4.46 & 3.48 & 0.55 \\
\hline $\begin{array}{l}\text { Problem- } \\
\text { solving } \\
\text { Reading } \\
\text { Strategies }\end{array}$ & 54 & 2.38 & 4.63 & 3.69 & 0.50 \\
\hline $\begin{array}{c}\text { Support } \\
\text { Reading } \\
\text { Strategies }\end{array}$ & 54 & 2.00 & 4.56 & 3.41 & 0.54 \\
\hline $\begin{array}{c}\text { Overall } \\
\text { Reading } \\
\text { Strategies }\end{array}$ & 54 & 2.10 & 4.51 & 3.53 & 0.46 \\
\hline
\end{tabular}

TABLE VII: OVERALL FREQUENCY AND LEVEL OF READING STRATEGIES

\begin{tabular}{|c|c|c|c|c|}
\hline Usage & Global RS & $\begin{array}{c}\text { Problem-sol } \\
\text { ving RS }\end{array}$ & Support RS & Overall RS \\
\hline High & $25(46.3 \%)$ & $\mathbf{4 0}(\mathbf{7 4 . 1 \% )}$ & $22(40.7 \%)$ & $\mathbf{2 6 ( 4 8 . 1 \% )}$ \\
\hline Moderate & $\mathbf{2 7 ( 5 0 . 0 \% )}$ & $13(24.1 \%)$ & $\mathbf{2 8}(\mathbf{5 1 . 9 \%})$ & $25(46.3 \%)$ \\
\hline Low & $2(3.7 \%)$ & $1(1.9 \%)$ & $4(7.4 \%)$ & $3(5.6 \%)$ \\
\hline Total & $54(100 \%)$ & $54(100 \%)$ & $54(100 \%)$ & $54(100 \%)$ \\
\hline
\end{tabular}

\section{DISCUSSION}

\section{A. Reading Strategies While Reading Academic Text}

The findings, indicate that undergraduate students in UTM have a high use of problem-solving reading strategies with $m=3.69$ which was higher than the rate for global reading strategies $(m=3.48)$ and support reading strategies $(m=3.41)$ as seen in Table VI. This finding is similar to Tengku Nor Rizan and Nooreiny [18], Alhaqbani and Riazi [19], Abdul Rahim et al. [20], Karbalaei [21] and Mónos [22] that showed that problem-solving reading strategies had the highest mean scores followed by global and support reading strategies. Adjusting reading speed when the text becomes difficult and Pause and think about the text were reported to be the most common strategies used by the students. This indicated that students were most likely to use problem-solving strategies to solve reading comprehension problems when the text is difficult. Read slowly but carefully for better understanding and Pause and think about the text were the most common strategies employed by the students when reading academic text in this study. Support reading strategies were the least frequent used strategies with the lowest mean of 3.41 (Refer to Table VI) and this is in line with the findings of Mónos [22]. This shows that students in UTM did not value the basic support mechanisms that aid comprehension to the extent that they are needed. Strategies such as going back and forth in the text and underline or circle information in text for better understanding were two common support strategies applied by all students in the study. This shows that students were using support mechanisms to help them find the main ideas of the text and to better understand the text whereas paraphrasing for better understanding or summarizing the 
text was the least common support strategies used by students. The findings showed that students were not able to use complex strategies such as paraphrasing or summarizing which requires good reading skills, thus they decided to utilize these strategies less frequently.

These findings demonstrate that undergraduate students in UTM are aware of how to apply metacognitive reading strategies when reading academic texts and this is supported by research such as Block [23] and Sheorey and Mokhtari [10]. O'Malley and Chamot [7] stated that metacognitive strategies are strategies which involve knowledge and learning control through planning, monitoring and evaluating learning activity. Correspondingly, Anderson [24] mentioned that second language students gained considerable success in all academic areas by improving reading comprehension. From this study, it is discovered that undergraduate students in UTM are able to plan, monitor and evaluate their learning activities by employing the appropriate metacognitive reading strategies whenever appropriate. As stated by Scarcella and Oxford [25], students employ learning strategies to improve their education. Oxford [26] asserted that metacognitive strategies which are indirect learning strategies help provide ways of regulating, coordinating, arranging, planning and evaluating learning. UTM undergraduate students select the appropriate metacognitive reading strategies when they are reading academic texts to understand the texts better. This shows that they already have metacognitive awareness as they are conscious of their actions and know what should be done when they face problems in reading academic texts. When students' consciously choose strategies that suit their learning, these strategies become a useful toolkit for active, conscious, and undergraduates are also ESL readers, these findings can be related to Sheorey and Mokhtari [10] who stated that non-native or ESL readers frequently adopt reading strategies appropriate to their situation or task. Similarly, Grabe [2] believed that readers must have some sort of expectation in order to understand what he/she is reading and to employ various strategies to read effectively. When reading academic texts, UTM undergraduates set their objectives and identify the level of difficulty of the text so that they are able to select suitable reading strategies that match the texts difficulty. Difficult and complex texts require undergraduates to utilize additional strategies. This could be the reason for the high frequency of problem-solving strategies used by UTM undergraduates compared to both global and support reading strategies. Problem-solving strategies were the most frequently used strategies by undergraduates because they found these strategies useful for helping them to understand the text.

\section{CONCLUSION}

The objectives of the study were to investigate the metacognitive reading strategies used by undergraduate students while reading academic texts. The findings show that when students have difficulties in comprehending academic texts they tend to use more problem-solving reading strategies than global or support reading strategies. The findings indicated that students are not focusing on knowing the most effective strategies, but rather on how to use strategies effectively and appropriately. Therefore, they were able to identify suitable metacognitive reading strategies that should be employed on different types of academic texts because they were able to apply the accurate strategy when they find the text becoming difficult.

\section{REFERENCES}

[1] M. Pressley and P. Afflerbach, Verbal Protocols of Reading: The Nature of Constructively Responsive Reading, Hillsdale, NJ: Erlbaum, 1995.

[2] W. Grabe, "Current developments in second language reading research," TESOL Quarterly, vol. 25, no. 3, pp. 375-406, 1991.

[3] L. Baker and A. L. Brown, "Metacognitive skills and reading," in D. P. Pearson (Ed.), Handbook of Reading Research, New York: Longman, 1984, pp. 353-394.

[4] W. Shmais, "Identifying the metacognitive reading strategies of Arab University students: A case study," An-Najah Univ. J. Res (H.Sc.), vol. 16, no. 2, 2002.

[5] F. Cubukcu, "Enhancing vocabulary development and reading comprehension through metacognitive strategies," Issues in Educational Research, vol. 18, no. 1, pp. 1-11, 2008

[6] N.J. Anderson, "The role of metacognitive in second language teaching and learning," ERIC Digest, 2002.

[7] J. M. O' Malley and A. U. Chamot, Learning Strategies in Second Language Acquisition, Cambridge: Cambridge University Press, 1990.

[8] R. E. Slavin, Educational Psychology: Theory and Practice, Boston, MA: Allyn \& Bacon, 2006.

[9] A. L. Brown, "The advancement of learning," Educational Researcher, vol. 23, no. 8, pp. 4-12, 1994.

[10] R. Sheorey and K. Mokhtari, "Differences in the metacognitive awareness of reading strategies among native and non-native readers," System: An International Journal of Educational Technology and Applied Linguistics, vol. 29, pp. 431-449, 2001.

[11] A. L. Brown, "Metacognition, executive control, self-regulation, and other more mysterious mechanisms," in F. E. Weinert and R. H. Kluwe (Eds.), Metacognition, Motivation and Understanding, Hillsdale, New Jersey: Lawrence Erlbaum Associates, pp. 65-116, 1987.

[12] A. L. Wenden, "Metacognitive knowledge and language learning," Applied Linguistics, vol. 19, no. 4, pp. 515-537, 1998.

[13] C. Magno, "Reading strategies, amount of writing, metacognition, metamemory and apprehension as English written Proficiency," Asian EFL, vol. 29, July 2008.

[14] K. Mokhtari and C. Reichard, "Assessing students' metacognitive awareness of reading strategies," Journal of Educational Psychology, vol. 94 , no. 2 , pp. 249-259, 2002.

[15] C. E. Snow, M. S. Burns, and P. Griffin, "Preventing reading difficulties in young children," Washington DC: National Academy Press, 1998.

[16] S. G. Paris and P. Winograd, "How metacognition can promote academic learning in instruction," in B. F. Jones \& L. Idol (Eds), Dimension of Thinking and Cognitive Instruction, Hillsdale, NJ: Erlbaum, pp. 15-51, 1990.

[17] J. H. Flavell, "Metacognition and cognitive monitoring: A new era of cognitive development enquiry," American Psychologist, vol. 34, no. 10, pp. 906-911, 1979

[18] T. M. M. T. N. Rizan and M. Nooreiny, "Empowering ESL readers with metacognitive reading strategies," Procedia-Social and Behavioral Sciences, vol. 6, pp. 1250-1258, 2011.

[19] A. Alhaqbani and M. Riazi, "Metacognitive awareness of reading strategy use in Arabic as a second language," Reading in a Foreign Language, vol. 24, no. 2, pp. 231-255, 2012.

[20] H. A. Rahim, G. M. Najib, S. A. Johari, and A. Sohaila, "The cognitive and metacognitive reading strategies of foundation course students in teacher Education institute in Malaysia," European Journal of Social Sciences, vol. 13, no. 1, pp. 133-144, 2010.

[21] A. Karbalaei, "A comparison of the metacognitive reading strategies used by EFL and ESL readers," The Reading Matrix, vol. 10, no. 1, pp. 165-180, 2010.

[22] K. Monos, "A study of the English reading strategies of Hungarian University students with implications for reading instruction in an academic context," Malaysian Journal of ELT Research, pp. 1-23, 2005.

[23] E. Block, "See how they read: Comprehension monitoring of L1 and L2 readers," TESOL Quarterly, vol. 20, pp.463-494, 1992. 
[24] N. J. Anderson, Exploring Second Language Reading: Issues and Strategies, Boston: Heinle \& Heinle Publishers, 1999.

[25] R. Scarcella and R. Oxford, The Tapestry of Language Learning: The Individual in the Communicative Classroom, Boston: Heinle \& Heinle Publishers, 1992.

[26] R. Oxford, Language Learning Strategies: What every Teacher should Know, Mass: Heinle \& Heinle Publishers, 1990.

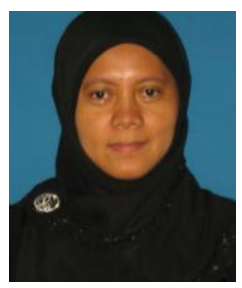

Azizah Rajab is an associate professor at the Language Academy, Universiti Teknologi Malaysia, Johor Bahru Campus. She obtained her $\mathrm{PhD}$ in applied linguistics from Leicester University, United Kingdom in 1996. She is with UTM for more than 27 years and currently active in research related to second language, educational psychology, higher education and social science.

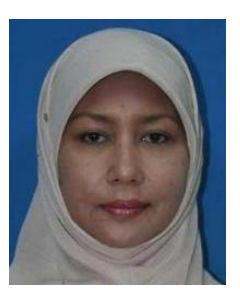

Hamidah Abdul Rahman is a senior lecturer at the Faculty of Management, Universiti Teknologi Malaysia, Johor Bahru Campus. She obtained her Mphil in sociology from Universiti Malaya in 1989. She is currently active in research related to social science and human resource training.

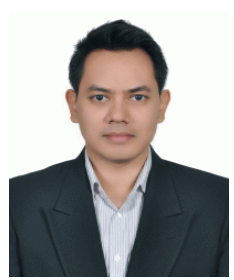

Shah Rollah Abdul Wahab is a senior lecturer at the Faculty of Management, Universiti Teknologi Malaysia, Johor Bahru Campus. He obtained his PhD in management from Universiti Teknologi Malaysia, Malaysia in 2011. He is with UTM for more than 12 years and currently active in research related to safety management, transformational leadership and employee training.

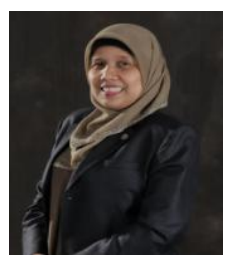

Faizah Mohd Nor is an associate professor at the Language Academy, Universiti Teknologi Malaysia, Johor Bahru Campus. She obtained her PhD in TESL from UTM and has been working with the same institution for more than 21 years and her research include English for specific purposes, teacher training and ELT.

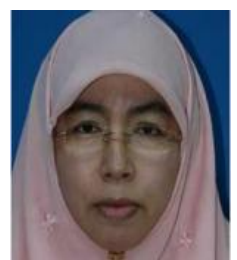

Wan Zarina Wan Zakaria is a senior lecturer at the Language Academy, Universiti Teknologi Malaysia, Johor Bahru Campus. She obtained her MED in curriculum and instruction from Ohio University, USA in 1988. She is with UTM for more than 25 years and currently active in research related to ESL, education psychology, teacher training and literature.

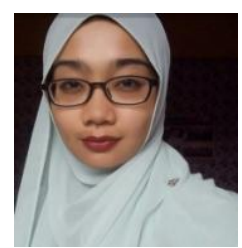

Wan Zahidah Rajim obtained her bacheclor of education (TESL) degree from Faculty of Education, Universiti Teknologi Malaysia, Johor Bahru Campus in 2015. She resided in Kota Kinabalu, Sabah and her research interest include teacher training, second language learning, ELT and English for specific purpose. 